Bochenek M., The issue of value in economic thought - Part 2: the evolution of views from 1871 until the second half of the $20^{\text {th }}$ century, „Ekonomia i Prawo. Economics and Law”, Polszakiewicz B., Boehlke J. (ed.), Vol. 14, No. 3/2015, pp. 315-326. DOI: http://dx.doi.org/10.12775/ EiP.2015.020.

\title{
MIROSŁAW BOCHENEK
}

\section{THE ISSUE OF VALUE IN ECONOMIC THOUGHT - PART 2: THE EVOLUTION OF VIEWS FROM 1871 UNTIL THE SECOND HALF OF THE $20^{\text {TH }}$ CENTURY}

\author{
SUMMARY
}

This paper is devoted to the evolution of views on value propounded in the period from 1871 until the second half of the $20^{\text {th }}$ century. The creators of the scientific revolution in economics called the marginal revolution rejected the classical interpretation of value understood objectively, and developed a subjective theory of value. According to W.S. Jevons, economists should focus only on exchange value, which expresses the ratio of exchangeability of some goods for others. A. Marshall combined the issues of value and price with the theories of supply and demand. J.B. Clark made the value of goods dependent on their effective utility, which constitutes the significance that an individual attaches to satisfying a given need. For C. Menger value represents the importance that individuals attribute to particular goods, serving to satisfy those individuals' needs. Expanding C. Menger's views, E. von Böhm-Bawerk and F. von Wieser claimed that the value of goods is determined by their border use (marginal utility). L.M.E. Walras maintained that the exchange value of goods is determined by their rarity. In the $20^{\text {th }}$ century, J.R. Hicks and K.E. Boulding, who based the theory of value on choice theory, and finally, P.A. Samuelson, according to whom the value of a commodity is determined by the point of market equilibrium, dealt with the modification of the neoclassical

" Mirosław Bochenek, Nicolaus Copernicus University, Faculty of Economic Sciences and Management, Department of Economics, ul. Gagarina 13A, 87-100 Toruń, Poland, phone: +48 5661148 96, e-mail: bochenek@econ.umk.pl. 
theory of value. Proposals by V. Pareto, G.K. Cassel and W.M. Zawadzki to remove the category of value from economics confront contemporary economists with the task of searching for, and possibly determining a new source and measure of value of goods and services.

Keywords: history of the economic thought; theory of value

JEL Classification: B13; B20

\section{INTRODUCTION}

Most $19^{\text {th }}$ - and $20^{\text {th }}$-century economists did not challenge the constitutive role of the theory of value in economics. The theory of value belonged to the most sophisticated and abstract concepts. It even seemed that as long as there was the science of economics, value would be treated as the central economic category. Meanwhile, at the beginning of the $20^{\text {th }}$ century, three theorists proposed to remove this concept from economics. Although their proposals did not find much resonance in the economic environment, the category of value has become a category less frequently or occasionally used. Therefore, the subject of these considerations is the views of the most prominent $19^{\text {th }}$ - and $20^{\text {th }}$-century economists on the theory of value and its prospects. The method of historical analysis was applied in developing this article.

\section{THE THEORY OF VALUE ACCORDING TO THE DEVELOPERS OF THE SUBJECTIVE-MARGINAL MOVEMENT}

An outline of the subjective theory of value along with the principle of marginal utility was presented by William Stanley Jevons in 1862, in an article under the title Brief Account of a General Mathematical Theory of Political Economy, while he presented a systematic lecture on the theory of utility and the theory of value in his treatise under the title The Theory of Political Economy, published in 1871. The founder of the neo-classical school emphasized the relative nature of the concept of value, claiming that exchange value reflects only the ratio of exchangeability and nothing else. He believed that instead of deliberating about the cause of value or the relation of value to the price, we should rather examine the conditions governing the ratio of exchangeability of some goods for others. Discussions about the origin of value should be considered futile. As appears from an analysis conducted by W.S. Jevons, the quantity of goods subject to exchange is in inverse proportion to their final degrees of utility. As a result of exchange, the lev- 
elling of the sum of utility and unpleasantness occurs. This means that exchange leads to levelling the final degrees of utility of exchanged goods for all participants in the exchange. According to W.S. Jevons, the exchange value of goods depends on the final degree of their utility. In his reasoning he rejected D. Ricardo's and J.S. Mill's views that exchange value is based on production costs, determined by the relative amounts of labour. The views of the classical economists were overly simplistic as they pointed to the impact of production costs on exchange value, since we should take into account the fact that production costs are a determinant of supply, which in turn determines the final degree of utility, and this determines value. Since labour is diverse in type and quality, which is why its different types should not be compared, it cannot therefore be treated as a cause of value. The value of a product is determined by the value of labour, and not vice versa ${ }^{1}$.

According to Alfred Marshall's theory presented in the book under the title Principles of Economics (1890), the issues of value and the price should be based on the theory of supply and demand. The theory of demand is related to the theory of marginal utility, whereas the theory of supply to the theory of production costs ${ }^{2}$.

John Bates Clark believed that the proper method of reasoning in economics is marginalism and subjectivism, which allows the formulation of the theory of value. In his book under the title Essentials of Economic Theory as Applied to Modern Problems of Industry and Public Policy (1907), he argued that wealth, being a subject of studies in economics, consists of useful material goods which satisfy people's needs. Owing to their scarcity, goods play an important role in man's life, whereas their property of satisfying needs decides their absolute utility. Their scarcity causes that each unit of goods is attached significance to satisfy needs, which is referred to as "effective utility". Absolute utility of goods and their scarcity are considered conditions of effective utility. Effectively utility determines the value of goods, while the product of the effective utility of a unit of goods and the number of units of goods determines the value of a supply of goods. On the other hand, the unpleasantness accompanying work is a cost in the form of negative utility, which expresses the unpleasantness of a unit of labour. Increasing workload results in an increase in unpleasantness, which is reflected in an increase in labour costs, which is accompanied by a decrease in productivity, when the amount of the capital involved does not increase. This argumentation allowed the American

${ }^{1}$ W.S. Jevons, The Theory of Political Economy, Macmillan and Co., London and New York 1871, pp. 95-132.

${ }^{2}$ A. Marshall, Principles of Economics, $8^{\text {th }}$ edition, Macmillan, London 1947, p. $18 \mathrm{ff}$. 
economist to formulate a conclusion that the exchange value and quantity of goods (volume) are determined by the point at which decreasing effective utility is equal to increasing cost. In other words, exchange value is determined by marginal utility and marginal cost ${ }^{3}$.

Independently of W.S. Jevons, an original subjective theory of value was also developed by Carl Menger. In his book bearing the title Grundsätze der Volkswirtschaftslehre (1871), he took the view that economics deals only with economic goods, i.e. with goods whose quantity is limited compared to the demand. Economic goods are the only goods that have value. But things become goods only when economic man becomes conscious of this property of goods, and disposes of those goods. Too small an amount of goods in comparison with economic man's needs for these goods causes them to become important to his well-being. C. Menger interpreted value as the significance an individual attaches to specific goods. For individuals are aware that possessing goods decides the satisfaction of their needs. Economic goods have value only if they are useful for individuals and limited in relation to their needs. The category of value belongs to subjective phenomena. It is not an internal feature of goods. A condition of value is rarity and the subjective liking and evaluation of economic man. According to a subjective presentation of value, every human being attributes a different value to the same goods. The quantity of value depends on subjective and objective factors. Subjective and objective factors are taken into account in the calculations of an economic entity, which estimates each unit of the goods held. In evaluating the significance of goods, economic man takes into account the ranks of needs and the degree of their satisfaction. The value of goods is determined by the intensity of satisfaction, or marginal utility. Some economic goods have more applications, which means they can satisfy different needs. According to the law formulated by C. Menger, the value of individual units of supply of given goods is determined by the smallest significance in satisfying different needs. If any goods can be replaced by other goods, the value of the former may depend on the value of the substitute goods. This means that the value of goods of a higher order is determined by the value of lower order goods ${ }^{4}$.

C. Menger's theory of value was supplemented and further developed by Eugen von Böhm-Bawerk in his books Verhältnisse Recht und der vom Standpunkte volkswirtschaftlichen Güterlehre (1881) and Kapital und Kapitalzins

3 J.B. Clark, Essentials of Economic Theory as Applied to Modern Problems of Industry and Public Policy, The Macmillan Company, New York 1907, p. 5 ff.

${ }^{4}$ C. Menger, Grundsätze der Volkswirtschaftslehre, erster, Allgemeiner Theil, Wilhelm Braumüller - K.K. Hof- und Universitäts-Buchhändler, Vienna 1871, pp. 77-152. 
(2 vol., 1884-1889). According to this economist, people are interested in useful goods and make their evaluation. Value is a complex category. It includes subjective value and objective value. Objective value exists in the form of technical objective value and exchange objective value. E. von BöhmBawerk understood technical objective value as the physical ability of goods to cause effects objective in nature, while he viewed exchange objective value as the ability to obtain substitute goods in the process of exchange. In turn, subjective value is interpreted as the significance that an economic entity attaches to goods from the point of view of benefits forming their well-being. It manifests itself in the form of the subjective utility value and the subjective exchange value. Subjective utility value is the significance of goods from the point of view of well-being, which is formed by directly satisfying needs. Subjective exchange value is the significance of goods through which needs can be indirectly satisfied through an exchange for other goods. In contrast, the ratio of exchangeability, at which some goods are exchanged for a certain amount of other goods, is the price. A condition for the formation of subjective utility value is the scarcity of goods compared to the needs. The amount of the subjective utility value of goods is decided by the amount of resulting benefits, understood as the utility that creates well-being, i.e. it is determined by the intensity of a satisfied need. Subjective utility value is determined by the least important need which a given unit of goods caters for, i.e. the lowest utility, or marginal (border) utility. The sum of the utility of individual units is the subjective utility value of the entire supply owned, or the total utility of goods. In the case of the phenomenon of substitution, the value of replaceable goods is determined by the lower marginal utilities of substitute goods. Thus, substitute value is a basis for determining the subjective exchange value whose amount is determined by the marginal utility of goods acquired by an economic entity as a result of exchange for goods given away. Therefore, E. von Böhm-Bawerk concluded that subjective value is affected by both utility and rarity, and these in turn are closely related to marginal utility. However, subjective value is ultimately determined by the mutual relationships of supply and demand of individual economic entities, i.e. individual supply and demand. Since different economic entities define different values, the phenomenon of exchange is justified ${ }^{5}$.

${ }^{5}$ E. Böhm-Bawerk, Rechte und Verhältnisse vom Standpunkte der volkswirtschaftlichen Güterlehre. Kritische Studie, Verlag der Wagner'schen Universitaets-Buchhandlung, Innsbruck 1881, p. 14 ff.; E. Böhm-Bawerk, Kapital und Kapitalzins, Zweite Abteilung: Positive Theorie des Kapitales, Verlag von Gustav Fischer, Jena 1921, pp. 158-205; E. Böhm-Bawerk, Kapitat i zysk 
Friedrich von Wieser's significant contribution to the theory of the psychological school is his generalization of the subjective theory of value, presented in three papers: Über den Ursprung und die Hauptgesetze des wirthschaftlichen Werthes (1884), Der natürliche Werth (1889) and Gesellschaftlichen theorie der Wirtschaft (1914), in which he simplified E. von Böhm-Bawerk's structure. F. von Wieser insisted that next to personal (subjective) utility value and personal exchange value, there is an (objective) economic exchange value defined as the ratio of exchangeability of goods. Exchange value expressed in money constitutes the price. The value of each item of goods is determined by "marginal utility" ("Grenznutzen"), i.e. the lowest utility of the last unit of goods. The value of a supply is the product of the amount of goods and marginal utility ${ }^{6}$.

In his book Éléments d'économie politique pure, ou théorie de la richesse sociale (2 vol., 1874-1877), Léon Marie Esprit Walras insisted that the object of study of political economy is social wealth. Social wealth comprises rare goods, both material and immaterial in nature. Rare goods include limited and useful items. Utility is the ability of goods to satisfy needs either directly or indirectly. In contrast, rarity was understood by the founder of the Lausanne School as the ratio of utility to the amount of goods, i.e. the utility represented by a unit of goods. Due to their rarity, goods are valued, appropriated and exchanged. The basis for the exchange of goods is the exchange value they possess. The ratio of exchange values is the price, which may be expressed in money, or in other goods. The task of the theory of value was to explain the mechanism of price formation. According to the founder of the Lausanne School, some things will be exchanged for other things according to a specified quantitative ratio. Value is inherently quantitative in nature. The price of individual goods, which is determined on the competitive market, must be uniform, i.e. it must equate effective demand with supply. In other words, the equilibrium price is equal to the ratio of rarity, and therefore the price,

z kapitatu, Dział drugi: Pozytywna teoria kapitatu, [in:] Wartość i cena. Wypisy z dziet autorów polskich i obcych, Wydawnictwo Kazimierza Rutskiego, Warszawa — Łódź 1949, pp. 237-267.

${ }^{6}$ F. Wieser, Über den Ursprung und die Hauptgesetze des wirthschaftlichen Werthes, Alfred Holder - K.K. Hof- und Universitäts-Buchhändler, Wien 1884, p. 10 ff., F. Wieser, Theorie der gesellschaftlichen Wirtschaft, [in]: K. Bücher, J. Schumpeter, F. von Wieser (ed.), Grundriss der Sozialökonomik, 1. Abteilung: Wirtschaft und Wirtschaftswissenschaft, Verlag von J.C.B. Mohr (Paul Siebeck), Tübingen 1914, p. 143 ff.; F. Wieser, Der natürliche Werth, Alfred Holder K.K. Hof- und Universitäts-Buchhändler, Wien 1889, pp. 1-64. Chapter one of the last of the cited works of the Austrian economist was published in Polish: F. Wieser, Wartość naturalna, [in:] Wartośc i cena. Wypisy z dziet autorów polskich i obcych, Wydawnictwo Kazimierza Rutskiego, Warszawa - Łódź 1949, pp. 206-238. 
or exchange value, is proportional to the rarity of given goods. It follows that rarity determines exchange value ${ }^{7}$.

\section{THE THEORY OF VALUE IN $20^{\mathrm{TH}}$-CENTURY ECONOMICS}

$20^{\text {th }}$-century economists did not see a particular need to develop existing, or to create alternative, concepts of value. In-depth analyses of this subject were undertaken by only a few of them.

In the first half of the $20^{\text {th }}$ century, the neoclassical theory of value was reformulated by John Richard Hicks. In his treatise under the title Value and Capital (1939), he pointed out that the theory of value must abandon the theory of utility and subjective feeling of satisfaction. This theory must be based on two concepts, i.e. the indifference curves and the marginal rate of substitution. He believed that the concept of substitution is suitable for the study of relationships between economic quantities. Justifying the abandonment of the theory of utility, the author of Values and Capital wrote: "In every theory of value, it is necessary to be able to define exactly what is meant by a consumer's >> given needs $<<$ or $>>$ given tastes $<<"$. Measuring consumers' tastes without taking into account their subjective feelings is a merit of the marginal rate of substitution. In order to take into account objective market quantities, such as prices and a consumer's income, and to establish their relationship with the marginal rate of substitution and their impact on consumer decisions, J.R. Hicks introduced the "price line", equal to the budget constraint, also known as the "budget line". Establishing its position can indicate the indifference curve on which the consumer will be found, and determine the amount of goods purchased by the consumer. The author of Values and Capital insisted that the theory of choice is not limited to the theory of con-

${ }^{7}$ L. Walras, Éléments d'économie politique pure, ou théorie de la richesse sociale, Imprimerie L. Corbaz - Guillaumin - H. Georg, Lausanne - Paris - Bale 1874, pp. 3-31; 52-57; 64-124; L. Walras, Pierwiastki czystej ekonomii politycznej czyli teoria bogactwa spotecznego, [in:] Wartość i cena. Wypisy z dziet autorów polskich i obcych, Wydawnictwo Kazimierza Rutskiego, Warszawa - Łódź 1949, pp. 198-205; L. Walras, Théorie mathematique de la richesse sociale, Réimpression de l'édition 1883, Otto Zeller, Osnabrück 1964, p. 15 ff.

${ }^{8}$ J.R. Hicks, Wartośc i kapitat. Studia nad kilkoma podstawowymi zagadnieniami w teorii ekonomii, PWN, Warszawa 1975, pp. 63; 65-67; J.R. Hicks, Value and Capital. An Inquiry into Some Fundamental Principles of Economic Theory, $2^{\text {nd }}$ edition, At the Clarendon Press, Oxford 1974, pp. 16-19. 
sumer behaviour, since it can be used to build the theory of economic choices in general'.

Paul Anthony Samuelson wrote about the place of the theory of value in the science of economics in his textbook Economics. An Introductory Analysis (1948). The usefulness of the theory of value and prices consists in establishing conditions for the effectiveness of resource allocation in the economy. The categories of marginal utility and rarity are used to determine value. An increasing supply curve reflects the effect of the law of decreasing productivity. A decreasing demand curve indicates that rarer goods correspond to higher marginal utility, higher value and price, and lower demand. The point of intersection of supply and demand curves determines the level of the equilibrium price, which is formed on the market and, at the same time, determines the value of the goods being exchanged ${ }^{10}$.

In his book Beyond Economics. Essays on Society, Religion, and Ethics (1968), Kenneth Ewart Boulding justified the need for the existence of economics and its importance for economic development, and argued that economics is treated as a generalized theory of choice. Where there is a problem of choice, people have to make an evaluation ${ }^{11}$. "Value," K.E. Boulding wrote, "in the sense of what we are willing to give up in order to obtain a unit of something else, the so-called rate of transformation, is a phenomenon that we encounter in every imaginable field of human activity. For wherever there is a limit, wherever there is the >>either-or<< choice, the phenomenon of value appears. (...) Wherever resources are limited, a choice is necessary and value takes a real earthly shape" 12 . Pointing to the need to preserve the existing character and distinctiveness of economics as a scientific discipline, E.C. Boulding stated that "(...) economics is still a moral science. Its central problem is the issue of value, and value is just a step away from virtue"13.

9 J.R. Hicks, Wartośc i kapitat..., op. cit., p. 63 ff.; J.R. Hicks, Value and Capital..., op. cit., p. $16 \mathrm{ff}$.

${ }^{10}$ P.A. Samuelson, Economics. An Introductory Analysis, $5^{\text {th }}$ edition, McGraw-Hill Book Company, New York - Toronto - London 1961, p. 37 ff.

${ }^{11}$ K.E. Boulding, Czy ekonomia jest niezbędna?, [in:] A. Eukaszewicz (ed.), Ponad ekonomiq, Państwowy Instytut Wydawniczy, Warszawa 1985, pp. 29-33.

12 Ibidem, p. 33.

13 Ibidem, pp. 40-41. 


\section{PROPOSALS TO REMOVE THE THEORY OF VALUE FROM ECONOMICS}

The view that the theory of value serves as the foundation of theoretical systems of economics was not universally acknowledged. In the early $20^{\text {th }}$ century, a few economists appeared who questioned the usefulness of the category of value in the science of management of scarce resources.

Vilfredo Federigo Damaso Pareto intended to supplement and modify the entire system of the Lausanne School. As early as in his first book under the title Cours d'économie politique (2 vol., 1896-1897), he based the theory of value and price on the theory of utility. It was with reserve, however, that he approached the concept of utility, which can also be an objective quantity, in the sense of usefulness, as well as a subjective one. In view of this ambiguity, he replaced the concept of utility with a new term, i.e. "ophelimity". By ophelimity he understood the satisfaction achieved by a subject at increasing the supply of given goods by a certain amount ${ }^{14}$. In his treatise under the title Manuale di economia politica (1906), the Italian economist decided that the concept of ophelimity has a number of drawbacks since it is an immeasurable, relative and incomparable category. For this reason, the theory of prices based on the notion of ophelimity has to be rebuilt. According to V.F.D. Pareto, value is a metaphysical and useless concept, therefore, he removed it from his economic theories. At the same time, he suggested that the whole theoretical system of economics should be developed based on the theory of choice ${ }^{15}$.

Several years later, a negative attitude to the theory of value was expressed by Karl Gustav Cassel in such works as Theoretisch Sozialökonomie (1918) and Fundamental Thoughts in Economics (1925). According to G.K. Cassel, the foundation of the whole theoretical system of economics is the theory of prices. Bearing that in mind, he considered that the theory of value turns out to be an unnecessary construct. G.K. Cassel pointed out that the essence of the price of goods can be explained without reference to their value. The theory of value is useful in the science of money and it forms its integral part. Steeped in psychology, the theory of marginal utility is also of little usefulness. A sufficient starting point in the economic analysis is price. The way of determining prices based on observable quantitative external facts should

${ }^{14}$ V. Pareto, Cours d'économie politique, tome prime, F. Rouge Éditeur - Pichon Libraire Duncker \& Humblot, Lausanne - Paris - Leipzig 1896, pp. 3-17.

15 V. Pareto, Manuel d'économie politique, traduit sur l'édition italienne par of A. Bonnet, V. Giard \& E. Brière, Paris 1909, pp. 22-39; 145-161. 
be the focus of economics. In addition, price theory uses other principles that explain the relationship that exists between the price, being a given quantity, and supply and demand. Without a given price, the analysis of supply and demand becomes pointless. The price aims to level demand with supply ${ }^{16}$.

Władysław Marian Zawadzki also argued for the removal of the concept of value from economics. According to him, the concept of value was not invented by economists, but it was developed by economic life. The task of economists was to justify it theoretically. Attempts to endow the concept of value with objective characteristics did not withstand criticism since value does not constitute a category of its own, but only the ratio of exchangeability; it can be considered only as exchange value, identical with the price. Since the price, or exchange value, is determined by a huge amount of various factors, many $19^{\text {th }}$-century economists led by V.F.D. Pareto found the category of value useless, and removed it from the science of economics, whose primary task is to discover trends present in economic life ${ }^{17}$.

\section{CONCLUSIONS}

The authors of the marginal revolution, i.e. W.S. Jevons, C. Menger, L.M.E. Walras and their supporters did not question the role of the theory of value as the foundation of the scientific system of economics. However, they performed a thorough reconstruction of the whole theory of economics developed by the classical economists. They based their economic systems on completely new bases. One of the pillars of new theoretical systems was a new theory of value understood subjectively. W.S. Jevons, C. Menger and L.M.E. Walras rejected the theory of value based on the theory of production costs for the utility theory. The developers of the subjective theory of value felt that the value of goods is decided by subjectively understood utility, i.e. the feeling of an individual satisfying their needs. J.R. Hicks replaced the concept of utility with the theory of choice in order to endow the theory with quantitative, measurable nature. However, the classical objective and subjective (related to the subjective-marginal movement) presentations of the cate-

${ }^{16}$ G. Cassel, Theoretische Sozialökonomie, 4th edition, A. Deichertsche Verlagsbuchhandlung Dr. Werner Scholl, Leipzig 1927, p. 74 ff.; G. Cassel, Fundamental Thoughts in Economics, Ernest Benn, London 1929, p. 38 ff.

${ }_{17}$ W. Zawadzki, Przedmowa, [in:] Wartośc i cena. Wypisy z dziet autorów polskich i obcych, Wydawnictwo Kazimierza Rutskiego, Warszawa — Łódź 1949, p. 7-31; W. Zawadzki, O pojęciu wartości zamiennej, „Rocznik Prawniczy Wileński”, Vol. 1/1925, pp. 70-88. 
gory of value was not met with universal approval. V. Pareto, G.K. Cassel and W.M. Zawadzki recognized value as a metaphysical, unverifiable and outdated concept. Although their proposal was not ostentatiously accepted by the community of economists, many of them still marginalize, or in silence replace, the theory of value with the price theory, and explain the occurring phenomena and processes without the theory of value. Even the view of the function of money as a measure of value is replaced with the claim that it acts as an accounting unit, i.e. one of expressing prices. Economists should therefore summon up the courage either to confess whether they give up the category of value due to its vague, blurred expression or metaphysical nature, or to take up the challenge and develop a common approach that will result in a uniform interpretation of the nature and source of creating value and its measure.

\section{BIBLIOGRAPHY}

Böhm-Bawerk E., Kapitat i zysk z kapitatu, Dział drugi: Pozytywna teoria kapitatu, [in:] Wartość i cena. Wypisy z dziet autorów polskich i obcych, Wydawnictwo Kazimierza Rutskiego, Warszawa — Łódź 1949.

Böhm-Bawerk E., Kapital und Kapitalzins, Zweite Abteilung: Positive Theorie des Kapitales, Verlag von Gustav Fischer, Jena 1921.

Böhm-Bawerk E., Rechte und Verhältnisse vom Standpunkte der volkswirtschaftlichen Güterlebre. Kritische Studie, Verlag der Wagner'schen Universitaets-Buchhandlung, Innsbruck 1881.

Boulding K.E., Czy ekonomia jest niezbędna?, [in:] A. Łukaszewicz (ed.), Państwowy Instytut Wydawniczy, Warszawa 1985.

Cassel G., Fundamental Thoughts in Economics, Ernest Benn, London 1929.

Cassel G., Theoretische Sozialökonomie, $4^{\text {th }}$ edition, A. Deichertsche Verlagsbuchhandlung Dr. Werner Scholl, Leipzig 1927.

Clark J.B., Essentials of Economic Theory as Applied to Modern Problems of Industry and Public Policy, The Macmillan Company, New York 1907.

Hicks J.R., Value and Capital. An Inquiry into Some Fundamental Principles of Economic Theory, 2nd edition, At the Clarendon Press, Oxford 1974.

Hicks J.R., Wartośc i kapitat. Studia nad kilkoma podstawowymi zagadnieniami w teorii ekonomii, PWN, Warszawa 1975.

Jevons W.S., The Theory of Political Economy, Macmillan and Co., London and New York 1871.

Marshall A., Principles of Economics, 8 $^{\text {th }}$ edition, Macmillan, London 1947.

Menger C., Grundsätze der Volkswirtschaftslehre, erster, allgemeiner Theil, Wilhelm Braumüller - K. K. Hof- und Universitäts-Buchhändler, Wien 1871.

Pareto V., Cours d'économie politique, tome premier, F. Rouge Éditeur - Pichon Libraire - Duncker \& Humblot, Lausanne - Paris - Leipzig 1896. 
Pareto V., Manuel d'économie politique, traduit sur l'édition italienne par A. Bonnet, V. Giard \& E. Brière, Paris 1909.

Samuelson P.A., Economics. An Introductory Analysis, $5^{\text {th }}$ edition, McGraw-Hill Book Company, New York - Toronto — London 1961.

Walras L., Éléments d'économie politique pure, ou théorie de la richesse sociale, Imprimerie L. Corbaz - Guillaumin - H. Georg, Lausane - Paris - Bale 1874.

Walras L., Pierwiastki czystej ekonomii politycznej czyli teoria bogactwa spotecznego, [in:] Wartośc i cena. Wypisy z dziet autorów polskich i obcych, Wydawnictwo Kazimierza Rutskiego, Warszawa — Łódź 1949.

Walras L., Théorie mathématique de la richesse sociale, Réimpression de l'édition 1883, Otto Zeller Osnabrück 1964.

Wieser F., Der natürliche Werth, Alfred Hölder - K. K. Hof- und Universitäts-Buchhändler, Wien 1889.

Wieser F., Theorie der gesellschaftlichen Wirtschaft, [in:] K. Bücher, J. Schumpeter, F. von Wieser (ed.), Grundriss der Sozialökonomik, 1. Abteilung: Wirtschaft und Wirtschaftswissenschaft, Verlag von J. C. B. Mohr (Paul Siebeck), Tübingen 1914.

Wieser F., Über den Ursprung und die Hauptgesetze des wirthschaftlichen Werthes, Alfred Hölder - K. K. Hof- und Universitäts-Buchhändler, Wien 1884.

Wieser F., Wartość naturalna, [in:] Wartość $i$ cena. Wypisy z dziet autorów polskich i obcych, Wydawnictwo Kazimierza Rutskiego, Warszawa — Łódź 1949.

Zawadzki W., O pojęciu wartości zamiennej, „Rocznik Prawniczy Wileński”, Vol. 1/1925.

Zawadzki W., Przedmowa, [in:] Wartość i cena. Wypisy z dziet autorów polskich i obcych, Wydawnictwo Kazimierza Rutskiego, Warszawa — Łódź 1949. 